\title{
Impact of Thyroid Hormones on Serum Prostate Specific Antigen Level in Patients with Benign Thyroid Disorders
}

\section{Benign Tiroid Bozukluğu Olan Hastalarda Tiroid Hormonlarının Serum Prostat Spesifik Antijen Düzeyleri Üzerine Etkisi}

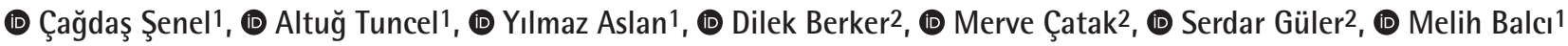 \\ 1 University of Health Sciences Turkiye, Ankara Numune Training and Research Hospital, Clinic of Urology, Ankara, Turkiye \\ 2 University of Health Sciences Turkiye, Ankara Numune Training and Research Hospital, Clinic of Endocrinology and Metabolism Diseases, \\ Ankara, Turkiye
}

\section{What's known on the subject? and What does the study add?}

Previous studies showed that patients with benign prostatic hyperplasia and prostate cancer have lower serum TSH and a higher serum T3 levels. Also it's known that PSA, the most common used biomarker in prostate cancer diagnosis is influenced by several factors. In the present study serum PSA levels in patients diagnosed with hypothyroidism and hyperthyroidism were measured and compared. In addition impact of medical treatment of these disorders on serum PSA levels were assessed. Our results showed that, lower serum TSH and higher serum T3 and T4 levels were associated with increased serum PSA levels.

\begin{abstract}
Objective: The aim of the present study was to evaluate whether thyroid hormone levels in benign thyroid disorders resulting in hypothyroidism or hyperthyroidism had an impact on the levels of serum prostate specific antigen (PSA).

Materials and Methods: A total of 50 male patients aged between 40 and 75 years who had newly diagnosed benign thyroid disorders were enrolled in this study. Patients with hypothyroidism $(n=19)$ were enrolled as group 1 and patients with hyperthyroidism ( $n=31)$ as group 2 . Before the initiation of medical treatment, levels of serum total, free PSA, and thyroid hormones were measured. Patients then received appropriate medical treatment for their thyroid disease. Once patients were noted to have achieved normal thyroid function tests in the second month following treatment initiation, serum total and free PSA levels were once again measured.

Results: The mean age of the patients was 56.7 years. The mean pretreatment serum total PSA levels in group 1 and $2 \mathrm{were} 1.5$ and $2.6 \mathrm{ng} / \mathrm{mL}$, respectively $(p=0.03)$. Although group 1 patients had lower posttreatment mean serum total PSA levels $(1.7 \mathrm{ng} / \mathrm{mL}) \mathrm{compared}$ to group 2 (2.5 $\mathrm{ng} /$ $\mathrm{mL})$, the difference was not statistically significant $(p=0.15)$. In the comparisons of pre and posttreatment serum total PSA, free PSA and free/total PSA (\%) levels in both groups, no statistically significant difference was found ( $p>0.05)$.

Conclusion: Our results showed that decreased serum thyroid stimulating hormone and increased serum T3 and T4 levels were associated with increased serum PSA levels. It was also observed that there was no alteration in serum PSA level in relationship to medical treatment received.

Keywords: Drug therapy, Prostate specific antigen, Thyroid diseases

Öz

Amaç: Bu çalışmada serum prostat spesifik antijen (PSA) düzeylerinin hipotiroidizm ve hipertiroidizm ile değişkenlik gösterip göstermediğini değerlendirmeyi amaçladık.

Gereç ve Yöntem: Yeni tanı almış benign tiroid bozukluğu olan 40-75 yaş arası 50 erkek hasta çalışmaya dahil edildi. Hastalar hipotiroidizmi olanlar $(n=19)$ grup 1 ve hipertiroidizmi olanlar $(n=31)$ grup 2 olarak ayrıldı. Medikal tedaviye başlanmadan önce serum total ve serbest PSA ile tiroid hormon düzeyleri ölçüldü. Sonrasında hastalar tiroid hastalığı için uygun tedavi başlandı. Tedavinin ikinci ayında tiroid fonksiyon değerleri normale gelen hastaların serum total ve serbest PSA değerleri yeniden ölçüldü.
\end{abstract}

Correspondence: Çağdaş Şenel MD, University of Health Sciences Turkiye, Ankara Numune Training and Research Hospital, Clinic of Urology, Ankara, Turkiye Phone: +90 5056311487 E-mail: cagdas_senel@hotmail.com ORCID-ID: orcid.org/0000-0002-4030-002X

Received: 13.02 .2020 Accepted: 12.05 .2020

Cite this article as: Şenel Ç, Tuncel A, Aslan Y, Berker D, Çatak M, Güler S, Balcı M. Impact of Thyroid Hormones on Serum Prostate Specific Antigen Level in Patients with Benign Thyroid Disorders. J Urol Surg 2020;7(4):290-294.

๑Copyright 2020 by the Association of Urological Surgery / Journal of Urological Surgery published by Galenos Publishing House. 
Bulgular: Hastaların ortalama yaşı 56,7 idi. Tedavi öncesi serum total PSA düzeyleri grup 1 ve 2'de sırası ile 1,5 ve 2,6 ng/mL ( $p=0,03$ ) idi. Grup 1'de tedavi sonrası serum total PSA düzeyleri $(1,7 \mathrm{ng} / \mathrm{mL})$ grup 2'den $(2,5 \mathrm{ng} / \mathrm{mL})$ daha düşük olmasına rağmen bu fark istatistiksel olarak anlamlı değil idi $(p=0,15)$. Her iki grupta tedavi öncesi ve sonrası serum total PSA, serbest PSA ve serbest/total PSA (\%) düzeyleri karşılaştırıldığında ise istatistiksel olarak anlamlı bir farklılık bulunmadı $(p>0,05)$.

Sonuç: Sonuçlarımız düşük serum ve yüksek serum T3 ile T4 düzeylerinin artmış serum PSA değerleri ile ilişkili olduğunu göstermiştir. Ayrıca çalışmamızda medical tedavi ile serum PSA düzeylerinde değişiklik olmadığı bulunmuştur.

Anahtar Kelimeler: İlaç tedavisi, Prostat spesifik antijen, Tiroid hastalıkları

\section{Introduction}

Serum prostate specific antigen (PSA) measurement has been widely used in screening (early detection), diagnosis, and monitoring treatment response in various stages of prostate cancer (PCa) (1). A major disadvantage of PSA-based PCa detection is the considerable number of false positive results that occur; many patients undergo unnecessary prostate biopsy procedures due to the false positive elevation in the serum PSA level. It is well documented that various diagnostic and therapeutic procedures, benign and physiologic conditions can elevate serum PSA concentration (2-7).

Although it is common knowledge that PSA is a prostatespecific marker, immunometric measurements have shown that low levels of PSA occur in several non-prostatic tissues, including thyroid, ileum, pancreas, trachea, seminal vesicle, mammary, and salivary glands (8). Although some earlier studies that measured thyroid hormone levels in patients with $\mathrm{PC}$ a and benign prostatic hyperplasia (BPH) have suggested a possible association between thyroid hormones and prostatic disorders (9-11), the precise impact of thyroid hormones on serum PSA levels remains unclear.

In this study, we evaluated whether the level of serum PSA can vary with benign thyroid diseases characterized by hypothyroidism or hyperthyroidism.

\section{Materials and Methods}

A total of 50 male patients aged between 40 and 75 years with newly diagnosed benign thyroid disorders characterized by either hypothyroidism or hyperthyroidism from the Endocrinology and Metabolism Diseases clinic were included in our study. All participants provided informed consent, and the study had the approval of the Institutional Ethics Committee. Following diagnosis, all patients were referred to our clinic for urological examination. Patients with active urinary tract infection, urologic cancer, urethral catheterization, acute or chronic renal failure, undergoing medical treatment for $\mathrm{BPH}$ liver dysfunction, thyroid malignancy, and those who had undergone urologic manipulations were excluded from the study. In addition, patients who continued to have abnormal thyroid function tests in the second month after initiating medical treatment were excluded.

Patients were divided into two groups. Patients with hypothyroidism $(n=19)$ were enrolled as group 1 , and patients with hyperthyroidism $(n=31)$ were enrolled as group 2 . Before commencing medical treatment, serum total/free PSA levels and thyroid function tests including serum thyroid stimulating hormone (TSH), triiodothyronine (T3), and thyroxine (T4) were measured. All patients subsequently received medical treatment for their thyroid disease as appropriate. Once the patients achieved normal thyroid function test results in the second month following treatment initiation, the above-mentioned parameters were once again estimated. All tests were performed by fluorometric immunoassay using a commercially available instrument.

\section{Statistical Analysis}

Statistical analysis was performed using Statistical Package for the Social Sciences (SPSS) 13.0 for Windows (SPSS Inc. Chicago, IL, USA). Kolmogorov-Smirnov test was used to confirm the normal distribution. A comparison was performed using t-test and Paired Samples t-test. A value less than 0.05 was considered statistically significant.

\section{Results}

The mean age of the patients in this study was 56.7 years. The mean ages of patients in group 1 and 2 were $56.8 \pm 8.9$ (40-70) and $56.5 \pm 10.6(41-75)$ years, respectively $(p=0.917)$. The mean pretreatment serum total PSA level in group 1 was $1.5 \pm 1.6(0.1$ to 5.8$) \mathrm{ng} / \mathrm{mL}$ and in group 2 was $2.6 \pm 3.1$ (0.4 to 15$) \mathrm{ng} / \mathrm{mL}$, $(p=0.03)$. Although group 1 patients had lower posttreatment mean serum total PSA levels $[1.7 \pm 1.7(0.3-5.9) \mathrm{ng} / \mathrm{mL}]$ compared to group $2[2.5 \pm 3.8(0.4-20.6) \mathrm{ng} / \mathrm{mL}]$, the difference was not statistically significant $(p=0.15)$. In the comparisons of pre and posttreatment serum total PSA, free PSA and free/total PSA (\%) levels in both groups, no statistically significant difference was found ( $p>0.05$ ). The results are summarized in Table 1 .

In total, seven patients were determined to have elevated serum total PSA levels ( $>4 \mathrm{ng} / \mathrm{mL}$ ). All of them had normal findings on digital rectal examination. The elevated serum total PSA levels 


\begin{tabular}{|c|c|c|c|c|c|c|}
\hline \multirow{2}{*}{ Variables } & \multicolumn{3}{|l|}{ Group $1(n=19)$} & \multicolumn{3}{|l|}{ Group $2(n=31)$} \\
\hline & Pretreatment & Posttreatment & $\begin{array}{l}\mathbf{p} \\
\text { value }\end{array}$ & Pretreatment & Posttreatment & $\begin{array}{l}p \\
\text { value }\end{array}$ \\
\hline Total PSA (ng/mL) & $1.5 \pm 1.6(0.1-5.8)$ & $1.7 \pm 1.7(0.3-5.9)$ & 0.142 & $2.6 \pm 3.1(0.4-15)$ & $2.5 \pm 3.8(0.4-20.6)$ & 0.526 \\
\hline Free PSA (ng/mL) & $0.4 \pm 0.5(0-1.9)$ & $0.5 \pm 0.6(0.1-2.6)$ & 0.423 & $0.6 \pm 0.5(0.1-2.3)$ & $0.6 \pm 0.7(0.2-3.1)$ & 0.081 \\
\hline Free/Total PSA ratio (\%) & $34 \pm 14(13-58)$ & $35 \pm 13(9-57)$ & 0.249 & $30 \pm 10(12-53)$ & $28 \pm 10(6-48)$ & 0.793 \\
\hline $\mathrm{TSH}(\mu \mathrm{IU} / \mathrm{mL})$ & $24.5 \pm 34.7(6-100)$ & $4.1 \pm 1.2(0.4-5.5)$ & & $0.1 \pm 0.1(0-0.3)$ & $1.7 \pm 1.5(0.4-5.4)$ & \\
\hline T3 (pg/mL) & $2.8 \pm 0.5(1.9-3.6)$ & $3.1 \pm 0.3(2.6-3.4)$ & & $5.5 \pm 4.5(2.624 .9)$ & $3.1 \pm 0.6(24.4)$ & \\
\hline $\mathrm{T} 4$ (ng/mL) & $0.6 \pm 0.3(0.1-1.2)$ & $0.9 \pm 0.2(0.7-1.2)$ & & $1.9 \pm 1.3(0.8-6.3)$ & $0.8 \pm 0.1(0.6-1.1)$ & \\
\hline
\end{tabular}

persisted even after they achieved normal thyroid function tests. Six of the seven patients belonged to group 2 and one of them belonged to group 1. All seven patients underwent transrectal ultrasound guided prostate biopsy, and all the histopathological examination results were consistent with $\mathrm{BPH}$.

\section{Discussion}

$\mathrm{PCa}$ is the most commonly diagnosed cancer in males in Europe (12). For decades, serum PSA has been the most important biochemical tumor marker used in the screening, diagnosis, and monitoring of patients with PCa (13). Although serum PSA is the most commonly used tumor marker in $\mathrm{PCa}$, levels may be elevated in benign conditions as well. Prior studies have shown that several benign disorders including $\mathrm{BPH}$, prostatitis, prostatic massage, prostate biopsy, urinary retention, urethral catheterization, endoscopic urological interventions, and ejaculation can influence serum PSA levels $(2-7,14)$.

Initially, PSA expression was believed to be specific to the prostate gland. However, immunometric studies have shown that PSA can also occur in various normal and malignant tissues including mammary glands, thyroid gland, placenta, pancreas, and body fluids including semen, amniotic fluid, breast milk, and saliva $(8,15-$ 19). Magklara et al. (20) demonstrated expression of both PSA and human glandular kallikrein 2 in thyroid tissue. In a study by Olsson et al. (8), the authors detected high levels of PSA transcripts in the thyroid gland using reverse transcription polymerase chain reaction test. They reported that extra-prostatic PSA can interfere with PSA assays in patients with benign urologic conditions.

Thyroid hormones play an important role in the development, differentiation, and growth of nearly all tissues in the body (21). Bilek et al. (22) reported a close relationship between rat ventral prostate and thyroid gland. Although it is very well known that thyroid hormone regulates thyrotropin-releasing hormone levels in the male reproductive system, including the prostate (23), the direct effect of thyroid hormones on the prostate is still unclear. In 2001, Lehrer et al. (9) evaluated the relationship between serum T3 levels and risk of recurrence in patients treated for localized PCa. In their study, 68 patients were divided into three risk groups, namely, low, moderate, and high risk. The authors reported an association between elevated serum T3 levels and an increased risk of recurrent prostate cancer. In 2002, the same group (10) compared serum T3 levels among patients with localized PCa $(n=161)$, patients with BPH $(n=20)$, and normal controls $(n=27)$. They demonstrated that patients with BPH had higher serum T3 levels compared to patients with PCa and patients with PCa had higher serum T3 levels compared to the control group. In 2005, Hsieh and Juang (11) reported that $\mathrm{T} 3$ increases cell proliferation in androgen-sensitive PCa cell lines. In a prospective study (24), including nearly 30.000 participants, the investigators reported that decreased levels of TSH was associated with a higher PCa risk.

In 2012, Mondul et al. (25) examined the association between circulating thyroid hormones and risk of PCa. In this study, serum TSH, T3, and T4 levels were compared between $\mathrm{PCa}$ $(n=402)$ patients and normal controls $(n=800)$. Serum PSA levels of the patients were not measured during the study. The authors reported that hypothyroid males have a lower risk of PCa compared to euthyroid males. In 2016, a prospective population-based cohort study by Khan et al. (26) reported that elevated T4 levels were associated with an increased risk of several types of cancer, including PCa. The authors also found an association between decreased TSH levels and increased rates of cancer although it was not significant. Recently, another population-based study (27) reported that decreased TSH and increased T4 levels were associated with an increased PCa risk. A recent study by Eldhose et al. (28) evaluated levels of thyroid hormones in BPH $(n=40)$ and controls $(n=40)$. In this study, patients with BPH had significantly lower serum TSH, higher serum T3, and PSA levels compared to controls. The authors believe that their results suggest that elevated $\mathrm{T} 3$ and reduced TSH levels may play a role in the development of BPH. Another recent study (29) compared the pituitary function in men with low PSA levels $(<0.1 \mathrm{ng} / \mathrm{mL})$ and normal PSA levels $(1-4 \mathrm{ng} / \mathrm{mL}$ ). 
It was found that patients in the low PSA level group had lower TSH levels compared to the normal PSA level group.

To our knowledge, no studies have evaluated serum PSA levels in benign thyroid disorders. In this study, the mean basal serum PSA level was significantly lower in patients who were hypothyroid compared to hyperthyroid patients. Moreover, medical therapy did not alter serum PSA levels in the two groups. In our study population, seven patients underwent prostate biopsy due to elevated serum PSA levels and the results of the histopathological examination were consistent with $\mathrm{BPH}$. Interestingly, six of them had hyperthyroidism.

\section{Study Limitations}

This study has some limitations. First, the sample size of our study was small. Second, certain factors that could impact serum PSA levels (e.g. prostate volume) were not evaluated in our study.

\section{Conclusion}

Our study found that decreased serum TSH and increased serum T3 and T4 levels were associated with increased serum PSA levels. Although the exact mechanism of how thyroid hormones influence serum PSA levels is still unclear, our findings did demonstrate that serum PSA levels were not altered in relation to medical treatment for benign thyroid diseases. Further studies are needed to validate the findings of our study.

\section{Ethics}

Ethics Committee Approval: The study had the approval of the Institutional Ethics Committee.

Informed Consent: All participants provided informed consent.

Peer-review: Internally peer-reviewed.

\section{Authorship Contributions}

Surgical and Medical Practices: D.B., M.Ç., S.G., M.B., Concept: Ç.Ş., A.T., D.B., Design: Ç.Ş., A.T., Y.A., D.B., Data Collection or Processing: D.B., M.Ç., S.G., Analysis or Interpretation: Y.A., S.G., M.B., Literature Search: Ç.Ş., A.T., M.Ç., S.G., M.B., Writing: Ç.Ş., A.T., Y.A.

Conflict of Interest: No conflict of interest was declared by the authors.

Financial Disclosure: The authors declare that they have no relevant financial.

\section{References}

1. Partin AW, Oesterling JE. The clinical usefulness of prostate specific antigen: update 1994. J Urol 1994;152:1358-1368.
2. Oesterling JE, Rice DC, Glenski WJ, Bergstralh EJ. Effect of cystoscopy, prostate biopsy, and transurethral resection of prostate on serum prostatespecific antigen concentration. Urology 1993;42:276-282.

3. Yuan JJ, Coplen DE, Petros JA, Figenshau RS, Ratliff TL, Smith DS, Catalona WJ. Effects of rectal examination, prostatic massage, ultrasonography and needle biopsy on serum prostate specific antigen levels. J Urol 1992;147:810-814.

4. Neal DE Jr, Clejan S, Sarma D, Moon TD. Prostate specific antigen and prostatitis. I. Effect of prostatitis on serum PSA in the human and nonhuman primate. Prostate 1992;20:105-111.

5. Deliveliotis C, Alivizatos G, Stavropoulos NJ, Makrychoritis K, Koutsokalis G, Kiriakakis Z, Kostakopoulos A, Dimopoulos C. Influence of digital examination, cystoscopy, transrectal ultrasonography and needle biopsy on the concentration of prostate-specific antigen. Urol Int 1994;53:186-190.

6. Nadler RB, Humphrey PA, Smith DS, Catalona WJ, Ratliff TL. Effect of inflammation and benign prostatic hyperplasia on elevated serum prostate specific antigen levels. J Urol 1995;154:407-413.

7. Klein LT, Lowe FC. The effects of prostatic manipulation on prostate-specific antigen levels. Urol Clin North Am 1997;24:293-297.

8. Olsson AY, Bjartell A, Lilja $H$, Lundwall A. Expression of prostate-specific antigen (PSA) and human glandular kallikrein 2 (hK2) in ileum and other extraprostatic tissues. Int J Cancer 2005;113:290-297.

9. Lehrer S, Diamond EJ, Bajwa AM, Kornreich R, Stagger S, Stone NN, Droller $M J$, Stock RG. Association between serum triiodothyronine (t3) level and risk of disease recurrence in men with localized prostate cancer. Prostate Cancer Prostatic Dis 2001;4:232-234.

10. Lehrer S, Diamond EJ, Stone NN, Droller MJ, Stock RG. Serum triiodothyronine is increased in men with prostate cancer and benign prostatic hyperplasia. J Urol 2002;168:2431-2433.

11. Hsieh ML, Juang HH. Cell growth effects of triiodothyronine and expression of thyroid hormone receptor in prostate carcinoma cells. J Androl 2005;26:422-428.

12. Ferlay J, Colombet M, Soerjomataram I, Dyba T, Randi G, Bettio M, Gavin A, Visser 0, Bray F. Cancer incidence and mortality patterns in Europe: Estimates for 40 countries and 25 major cancers in 2018. Eur J Cancer 2018;103:356-387.

13. Lima AR, Bastos Mde L, Carvalho M, Guedes de Pinho P. Biomarker Discovery in Human Prostate Cancer: an Update in Metabolomics Studies. Transl Oncol 2016;9:357-370.

14. Tarhan F, Demir K, Orcun A, Madenci OC. Effect of ejaculation on Serum Prostate-Specific Antigen concentration. Int Braz J Urol 2016;42:472-478.

15. Levesque M, Hu H, D'Costa M, Diamandis EP. Prostate-specific antigen expression by various tumors. J Clin Lab Anal 1995;9:123-128.

16. Elgamal AA, Ectors NL, Sunardhi-Widyaputra S, Van Poppel HP, Van Damme $B J$, Baert LV. Detection of prostate specific antigen in pancreas and salivary glands: a potential impact on prostate cancer overestimation. J Urol 1996;156:464-468.

17. Lövgren J, Valtonen-André C, Marsal K, Lilja H, Lundwall A. Measurement of prostate-specific antigen and human glandular kallikrein 2 in different body fluids. J Androl 1999;20:348-355.

18. Black MH, Diamandis EP. The diagnostic and prognostic utility of prostatespecific antigen for diseases of the breast. Breast Cancer Res Treat 2000;59:1-14

19. Malatesta $M$, Mannello $F$, Luchetti $F$, Marcheggiani $F$, Condemi L, Papa $S$, Gazzanelli G. Prostate-specific antigen synthesis and secretion by human placenta: a physiological kallikrein source during pregnancy. J Clin Endocrinol Metab 2000;85:317-321.

20. Magklara A, Cheung CC, Asa SL, Diamandis EP. Expression of prostatespecific antigen and human glandular kallikrein 2 in the thyroid gland. Clin Chim Acta 2000;300:171-180 
21. Goemann IM, Romitti M, Meyer ELS, Wajner SM, Maia AL. Role of thyroid hormones in the neoplastic process: an overview. Endocr Relat Cancer 2017;24:R367-R385.

22. Bilek R, Gkonos PJ, Tavianini MA, Smyth DG, Roos BA. The thyrotrophinreleasing hormone (TRH)-like peptides in rat prostate are not formed by expression of the TRH gene but are suppressed by thyroid hormone. J Endocrinol 1992;132:177-184.

23. Maran RR, Ravichandran K, Arunakaran J. Prostate-thyroid axis: prostatic TRH is one of the stimulators of thyroid hormone. Endocr Res 2001;27:143152.

24. Hellevik Al, Asvold BO, Bjøro T, Romundstad PR, Nilsen TI, Vatten U. Thyroid function and cancer risk: a prospective population study. Cancer Epidemiol Biomarkers Prev 2009;18:570-574.

25. Mondul AM, Weinstein SJ, Bosworth T, Remaley AT, Virtamo J, Albanes D. Circulating thyroxine, thyroid-stimulating hormone, and hypothyroid status and the risk of prostate cancer. PLoS One 2012;7:e47730.
26. Khan SR, Chaker L, Ruiter R, Aerts JG, Hofman A, Dehghan A, Franco OH, Stricker BH, Peeters RP. Thyroid Function and Cancer Risk: The Rotterdam Study. J Clin Endocrinol Metab 2016;101:5030-5036.

27. Chan YX, Knuiman MW, Divitini ML, Brown SJ, Walsh J, Yeap BB. Lower TSH and higher free thyroxine predict incidence of prostate but not breast, colorectal or lung cancer. Eur J Endocrinol 2017;177:297-308.

28. Eldhose A, Nandeesha H, Dorairajan LN, Sreenivasulu K, Arul Vijaya Vani $\mathrm{S}$. Thyroid and parathyroid hormones in benign prostatic hyperplasia. $\mathrm{Br} J$ Biomed Sci 2016;73:94-96.

29. Drincic A, Nguyen AT, Singh S, Zena M, Walters R, Friedman K, Anderson RJ. Pituitary evaluation in patients with low prostate specific antigen. Endocr Pract 2018;24:1030-1037. 